\title{
IMPLICATIONS FOR BRITAIN OF DEARER COAL
}

$\mathrm{T}$ HE British public have recently been shocked again by a substantial increase in the price of coal. A figure of 8 per cent increase has only to be repeated a few more times and a serious situation in industry may be realized, for coal must remain, in spite of the marked increase in the use of oil in all branches of industry in Britain in recent years, the basis of Britain's economy. The really serious feature of these repeated unfortunate movements in price is the impetus that the rise in the price of coal gives to price- and wage-increases everywhere. Unfortunately, there are economists who believe that a rise in the price of coal is the most effective means of inducing more efficiency in the use of coal. The fallacies of these views when applied to the existing situation are being abundantly shown by the sequence of events that seem to have become a repetitive feature of our present times. They occur in spite of the trend to replace coal by oil because the outlook reveals a possible increase in the shortage of coal occasioned by still greater demands for power in industry if Britain is to maintain her competitive position in world export markets. As a further feature of the trend towards the use of oil, there is the Prime Minister's recent warning of the danger of war that might arise from the need for the maintenance of oil supplies from the Middle East-a sorry picture and prospect for a country whose greatest mineral asset lies in her coal measures.

The Financial T'imes, in a leading article of May 29, directed attention to the fact that the formidable burden that is being forced upon British industry by the impact of dearer fuel, power and transport comes at a time when other raw materials are showing a downward trend in price - copper down 30 per cent from this year's peak, tin 16 per cent, lead and zinc 11 per cent below their 1956 peak and rubber 38 per cent. Wage increases are not in the present case the only cause of the rise in price, for the nettle of the accumulated deficit in the costs of raising coal and costs of the mine reconstruction programme had to be grasped, and the sooner the better. Where lie the remedies? Technical advances in fuel utilization have in the past contributed in a substantial measure to the advancement of Britain's economy; but such instruments of progress can only move at the natural rate at which the means in the form of finance and technical personnel become available. Thus the call for more technologists can only meet with response in the course of years, as in the case of the develop. ment of the use of atomic energy. Meanwhile, the situation promises to become desperate, bearing the threat of the effect of foreign competition in export markets. At the moment, the only sure sign seems to be that the loss of such markets is going to be the determining factor in the situation.

There does, however, remain one saving grace : the inherent good sense of the British race, and the strange ability to 'muddle through' in times of trouble. Put in more conventional, if less expressive, form, both the industrialist and the working man, when they finally recognize a dangerous situation, have a tactical genius for mastering that situation. They do the job another way to save both heat and energy, and, if necessary, labour. Thus 'automation' to the journaliat may be a magic word whereby to scare the uninitiated in a headline; to the engineer it is mechanization and instrumentation, employing techniques which he has probably been developing for many years. In spite of many statements to the contrary, Britain is as highly skilled in these arts as any other country. In such directions lie the ultimate solutions of our problems of rising costs, aided by the inherent characteristic of refusing to panic, how. ever black the approaching cloud.

R. J. SARJANT

\section{THE FUTURE OF METALLURGY}

\begin{abstract}
$A^{\mathrm{T}}$ the annual general meeting of the Institution of Metallurgists, held on May 15, Mr. G. L. Bailey, director of the British Non-Ferrous Metals Research Association, was installed as the new president. In his address, Mr. Bailey, after discussing the progress of the Institution, went on to consider the rather distant future of the metallurgical industries.

The vast majority of metals are used for traditional purposes which are neither particularly spectacular nor exciting; but if, for example, we were compelled to carry on without steel, copper or cast iron, the question of finding suitable substitutes would in many cases be surprisingly difficult. If the demand for a specific metal exceeds the supply, the first thing to happen is a change in what is, somewhat deplorably, known as 'the pattern of use'. In the first place, more readily available metals, such as aluminium, magnesium and, maybe, titanium, would come into more extensive use, and secondly, there would be increasing employment of non-metallic materials for purposes for which metals were previously used.
\end{abstract}

These are matters both of economics and of technical efficiency-if a plastic pipe has advantages over a metal one at the same price, it will be used. If it is not so good but a lot cheaper, it will still be used to some extent. This balance is an ever-changing one as new properties are discovered and new methods of production developed.

This factor, new methods of production, is one of basic importance. In connexion with estimates of known resources, it must be borne in mind that the detailed prospecting of ore body is usually carried out merely to ensure an adequate supply for a specific and limited term of years. As a result of some change of price, of the development of new methods of beneficiation or of extraction process, enabling a poorer grade of ore to be used more efficiently, what may not now be an economic ore body may well become one in the future. Aluminium, for example, is to-day produced from bauxite; but there are immense amounts of aluminium available in clays which could not, however, be used with existing knowledge except at much higher cost. 